УДК 378.147:629.5.072.8(043.3)

DOI:

Олександр Даниленко, кандидат педагогічних наук, завідувач кафедри навігації і управління судном Дунайського інституту Національного університету “Одеська морська академія”

\title{
ОСОБЛИВОСТІ ВИЗНАЧЕННЯ ПОКАЗНИКІВ СФОРМОВАНОСТІ ГОТОВНОСТІ МАЙБУТНІХ СУДНОВОДІЇВ ДО ПРОФЕСІЙНОЇ ДІЯЛЬНОСТІ
}

У статті представлено характеристику показників критеріӥв сформованості готовності майбутніх судноводїв до професійної діяльності. 3 'ясовано, щчо сформованість готовності майбутніх судноводіїв до професійної діяльності можна визначити за допомогою потребнісно-мотивачійного, иіннісноорієнтачійного, когнітивного, професійно-особистісного та практичного критеріїв. Сформованість готовності майбутніх судноводіїв до професійної діяльності може проявлятися на чотирьох рівнях: нульовому (критичному), першому (репродуктивному), другому (продуктивному) і третьому (творчому). Для вирішення наукового завдання щодо визначення показників кожного з критеріїв сформованості готовності майбутніх судноводіїв до професійної діяльності застосовано метод експертного опитування. Представлено показники кожного із визначених критеріїв.

Ключові слова: майбутні судноводії; морські заклади вищзӧ освіти; фахівці морськоӥ галузі; компетентнісний підхід; готовність до професійної діяльності; навігація і управління морськими суднами; критерії сформованості готовності.

Jim. 12.

Oleksandr Danylenko, Ph.D.(Pedagogy), Head of the Navigation and Ship Handling Department, Danube Institute of National University "Odessa Maritime Academy"

\section{PECULIARITIES OF DETERMINATION OF INDICATORS OF READINESS OF FUTURE NAVIGATORS FOR PROFESSIONALACTIVITY}

The article describes the characteristics of indicators of the criteria for the formation of readiness of future navigators for professional activities. It has been found out that the readiness of future navigators for professional activity can be determined by means of need-to-motivational, value-based, cognitive, professional-personal and practical criteria. The readiness of future navigators for professional activity can be formed at four levels: zero (critical), first (reproductive), second (productive) and third (creative). To solve the scientific problem of determining the indicators of each of the criteria for the formation of readiness of future navigators to professional activity, an expert survey method has been used. The article presents the indicators of each of the identified criteria. The indicators of the formation of the value sphere of future navigators are the idea of social and public importance of the profession, the attitude to a healthy lifestyle and sports, the attitude to other cultures and peoples etc. The indicators of the cognitive criterion are the knowledge of legal acts regarding the safety of human life at sea, of navigation and technical condition of ships, of the organization of service on the ship and the protection of the marine environment; the knowledge of the operation principles of modern electronic radar facilities and the like. The indicators of the practical criterion are the ability to maneuver and control the vessel in any conditions using appropriate positioning methods, the ability to plan voyages and to navigate in any conditions using appropriate plotting aid for sea and ocean routes and other methods. The indicators of professional and personal criterion are the ability to work in a team; goodwill, tactfulness; clarity and expressiveness of speech, sociability; emotional stability, self-control, endurance and others. To obtain quantitative data on the indicators of the criteria for the formation of readiness of future navigators for professional activities, it is advisable to use the results of written and oral questionnaire assessment, tests, written solutions to situational tasks, control and practical work, methods of psychological diagnosis and psychological tests.

Keywords: future navigators; maritime higher educational institutions; specialists in the maritime industry; competence-based approach; professional readiness; navigation and ship handling; criteria of readiness formation.

$\Pi$ остановка проблеми у загальному вигляді та її зв'язок із важливими науковими чи практичними завданнями. Необхідність визначення показників сформованості готовності майбутніх судноводіїв до професійної діяльності безпосередньо пов'язана із проблемою удосконалення системи їхньої неперервної професійної підготовки у морських закладах вищої освіти. На перебіг і якість цього процесу останнім часом впливає низка чинників, зокрема глобалізаційні процеси, професійна міграція, міжцивілізаційна взаємодія, а також посилена увага світової спільноти та міжнародних морських організацій до безпеки 


\section{ОСОБЛИВОСТІ ВИЗНАЧЕННЯ ПОКАЗНИКІВ СФОРМОВАНОСТІ ГОТОВНОСТІ МАЙБУТНІХ СУДНОВОДІЇВ ДО ПРОФЕСІЙНӦ̈ ДІЯЛЬНОСТІ}

судноплавства. Попри прогнози щодо зменшення кількості аварій морських суден шляхом удосконалення навігаційних засобів навпаки спостерігається тенденція до зростання аварійності. За даними різних джерел близько $70 \%$ аварій суден виникають через людські чинники (помилки команди судна). 3 огляду на це важливим $є$ покращення якості підготовки майбутніх судноводіїв до професійної діяльності шляхом моніторингу цього процесу. А показники сформованості готовності майбутніх судноводіїв до професійної діяльності $\epsilon$ важливими індикаторами якості процесу і результату неперервної професійної підготовки майбутніх судноводіїв.

Аналіз останніх досліджень і публікацій, в яких започатковано вирішення даної проблеми, та на які опирається автор. Особливості професійної підготовки майбутніх фахівців водного та морського транспорту були предметом уваги К. Ткаченка [11], С. Волошинова [4], Л. Герганова [5], О. Дягилевої [9], А. Погодаєвої [10] та інших. У публікаціях дослідників розкривалися й інші аспекти діяльності вищої школи морського профілю. У контексті дослідження представляють інтерес праці таких дослідників, як С. Білявець [3], О. Діденко [7], Л. Дудікова [8], Р. Мішенюк [7] та ін., які дотримуються думки, що у педагогічних експериментах для вимірювання рівня сформованості готовності до професійної діяльності (як результату навчання у ЗВО) доцільно використовувати ознаки (індикатори або показники), на основі яких проводиться оцінювання і які дозволяють отримати кількісні дані. При цьому критерій складається з окремих показників, які дозволяють отримати за допомогою конкретно-наукових методів кількісні дані. На цьому наголошують О. Барабанщиков і Н. Дерюгін, які вважають, що показник $є$ складником критерію [1]. Цю точку зору поділяє також С. Білявець, який вважає, що критерії представляють собою “сукупність (групу) індикаторів, об’єднаних певною ознакою”, а ступінь їх вияву виражаються конкретними показниками [2, 178].

Виділення невирішених раніше частин проблеми, що розглядається у статті. Однак серед широкого спектру дослідження відсутні публікації з питань розроблення і характеристики показників сформованості готовності майбутніх судноводіїв до професійної діяльності на сьогодні немає. Потрібно визначити такі індикатори (показники), які дозволять здійснювати об'єктивну діагностику процесу формування готовності майбутніх судноводіїв до професійної діяльності.

Метою статті $\epsilon$ визначення і характеристика показників сформованості готовності майбутніх судноводіїв до професійної діяльності.

Виклад основного матеріалу дослідження. 3 метою визначення критеріїв і показників сформованості готовності майбутніх судноводіїв до професійної діяльності доцільно врахувати результати оприлюднених досліджень.

Так, наприклад, О. Демченко вважає, що для оцінювання успішності професійної діяльності фахівців морського флоту можна використовувати критерій “відповідати”- володіння комунікативною компетентністю (судноводій має володіти принаймні трьома європейськими мовами, бути здатним до “роботи в команді”) [6]. За критерієм “добиватися” - фахівці морського флоту мають володіти компетентністю бути готовим до “швидкоплинних змін”, яких вимагають нестандартні виробничі ситуації. За критерієм “засіб реалізації мети" - володіти компетентністю виконання фахових операцій (тобто доведення професійних умінь до рівня автоматизованості). За критерієм "результат професійної діяльності" - фахівці морського флоту мають демонструвати “готовність досягати успішності (виявом якої, зокрема, можна розцінювати, з одного боку, матеріальну винагороду, матеріальну винагороду, a, з іншого - потребу у постійному професійному самовдосконаленні)" [6].

Однак ми будемо спиратися на позицію таких науковців як С. Білявець [3], О. Діденко [7], Л. Дудікова [8], Р. Мішенюк [7], які пропонують здійснювати вимірювання сформованості готовності до професійної діяльності на основі оцінювання проявів ії компонентів з урахуванням визначених показників.

Результати проведеного дослідження дозволили нам 3'ясувати, що структуру готовності майбутніх судноводіїв до професійної діяльності можна подати як сукупність мотиваційного, иіннісного, інформаційного, психологічного та операційного. 3 огляду на це критеріями сформованості готовності майбутніх судноводіїв до професійної діяльності обрано відповідно до іiі структури потребнісномотивачійний (слугує для діагностики мотиваційного компоненту), изіннісно-орієнтаційний (призначений для діагностики ціннісного компоненту), когнітивний (використовується для діагностики інформаційного компоненту), професійно-особистісний (застосовується для з'ясування сформованості психологічного компоненту) та практичний (слугує для діагностики операційного компонента) критерії. 


\section{ОСОБЛИВОСТІ ВИЗНАЧЕННЯ ПОКАЗНИКІВ СФОРМОВАНОСТІ ГОТОВНОСТІ МАЙБУТНІХ СУДНОВОДІЇВ ДО ПРОФЕСІЙНОЇ ДІЯЛЬНОСТІ}

Наступним етапом дослідження є визначення показників кожного із визначених критеріїв.

Необхідно зазначити, що обсяг емпіричного дослідження анонсованої проблеми є досить значним. Це пов'язано з необхідністю дослідження неперервної професійної підготовки майбутніх судноводіїв на двох рівнях вищої освіти (бакалаврському і магістерському). 3 огляду на це, у дослідженні ми виходили 3 того, що діагностичний апарат має бути зручним, забезпечувати отримання об'єктивних даних, якісно характеризувати педагогічне явище готовність до професійної діяльності, бути адекватними, валідними (оцінювати саме те, для чого призначений, бути адекватним тому явищу, для вимірювання якого його використовують) [2,84], дозволяти отримати кількісні параметри щодо сформованості кожного зі структурних компонентів готовності до професійної діяльності [12].

Для вирішення наукового завдання щодо визначення показників кожного $з$ критеріїв сформованості готовності майбутніх судноводіїв до професійної діяльності застосовано метод експертного опитування. Цей метод має низку особливостей, які стосуються добору фахівців експертів, організації опитування, методів аналізу отриманої інформації тощо. Оскільки експертне опитування нараховує декілька типів, нами було обрано індивідуальне опитування. Його особливість полягає в тому, що експерти працюють окремо, індивідуально. Вони не володіють інформацією про інших експертів і не знають позиції інших фахівців щодо предмету опитування. Дотримання таких вимог забезпечує отримання індивідуальних думок експертів максимально очищених від стороннього впливу.

Процедура визначення показників кожного 3 критеріїв сформованості готовності майбутніх судноводіїв до професійної діяльності за допомогою експертного оцінювання передбачала підбір експертів, розробку анкети, організацію та проведення опитування, обробку та інтерпретацію результатів експертного опитування.

Оскільки існують різні способи і методи підбору експертів (документальний, експериментальний, метод оцінки ефективності попередньої експертної діяльності, метод “снігової кулі”, метод голосування (атестації), метод самооцінки), то було обрано документальний метод. Він передбачає відбір експертів на основі соціальнодемографічних даних. За результатами відбору було визначено 12 експертів. До складу експертної групи ввійшли завідувачі кафедр, професори і доценти зі стажем педагогічної роботи понад 10 років. Щодо наукового ступеня, то 4 з них були докторами наук (у галузі педагогіки і технічних наук), а інші 8 - кандидати наук (у галузі педагогіки та технічних наук).

Безпосередньо для опитування експертів щодо показників критеріїв сформованості готовності майбутніх судноводіїв до професійної діяльності розроблено анкету, яка містить відкриті (передбачають вільну форму відповідей) і закриті (передбачають вибір одного із запропонованих інтерв'юером відповідей) запитання.

Узагальнення анкет дозволило визначити основні показники, рекомендовані групою експертів для отримання кількісних параметрів сформованості готовності майбутніх судноводіїв до професійної діяльності.

Зокрема показниками потребнісномотиваційного критерію сформованості готовності майбутніх судноводіїв до професійної діяльності є: вмотивованість до здобуття професійної освіти; усвідомлення соціальної значущості професії судноводія; моральне задоволення від підготовки до майбутньої професійної діяльності; інтерес до історичних традицій професії судноводія; усвідомлення матеріальних переваг, які надає професійна діяльність; бажання нести відповідальність за безпеку судна, команди, вантажів і пасажирів; усвідомлення професійної діяльності як авторитетної та такої, що приносить задоволення; інтерес до мобільного характеру майбутньої професії, що надає можливість працювати у зарубіжних судноплавних компаніях.

Опрацювання заповнених експертами анкет дозволило визначити показники ціннісноорієнтаційного критерію. До ували брали вітальні, соціальні, моральні, естетичні цінності, але основними були все ж професійні ціннісні орієнтації, що формуються у процесі професійної підготовки. Отже, до основних показників (індикаторів), які дозволяють отримати уявлення про сформованість ціннісної сфери особистості судноводія можна віднести: уявлення про соціальну і суспільну значимість професії; ставлення до здорового способу життя та занять спортом; ставлення до інших культур і народів; уявлення про родинні цінності, дружбу, соціальні контакти; ставлення до релігії та віри; ставлення до безпеки людського життя на морі та охорони морського навколишнього середовища, правового порядку на судні; уявлення про честь, гідність, дружбу, справедливість, вірність порядність; уявлення про професійний саморозвиток і самореалізацію; ставлення до морських традицій; уявлення про авторитет і престижність професії; 


\section{ОСОБЛИВОСТІ ВИЗНАЧЕННЯ ПОКАЗНИКІВ СФОРМОВАНОСТІ ГОТОВНОСТІ МАЙБУТНІХ СУДНОВОДЇ̈ ДО ПРОФЕСІЙНОӤ ДІЯЛЬНОСТІ}

усвідомлення дисципліни, законності і рівності всіх громадян перед законом.

На підставі експертного опитування показниками когнітивного критерію сформованості готовності майбутніх судноводіїв до професійної діяльності визначено: знання міжнародних і вітчизняних нормативно-правових актів відносно безпеки людського життя на морі, безпеки плавання, судноводіння, технічного стану суден, організації загальносуднової служби та охорони морського навколишнього середовища; знання морського права, Кодексу торговельного мореплавства України, положень міжнародних конвенцій та резолюцій; знання принципів роботи сучасних електронних радіолокаційних засобів, електронних картографічних навігаційноінформаційних систем (ЕКНІС), Глобальної морської системи зв'язку під час лиха й для забезпечення безпеки (ГМЗЛБ); знання аварійнорятувальної справи; знання англійської мови (морської специфіки); знання організації праці та управління, трудового законодавства, управління персоналом на судні та його підготовки; знання правил і особливостей маневрування та управління судном в будь-яких умовах; знання безпечної обробки, завантаження, розміщення, кріплення, догляду під час рейсу та розвантаження вантажів, та їхній вплив на безпеку людського життя й судна.

У результаті експертного опитування за допомогою анкети визначено такі показники практичного критерію: уміння маневрувати та управляти судном у будь-яких умовах із застосуванням відповідних методів визначення місцезнаходження, а також $з$ використанням сучасних електронних радіолокаційних засобів, електронних картографічних навігаційноінформаційних систем; уміння планувати рейс та здійснювати судноводіння у будь-яких умовах із застосуванням відповідних методів прокладки морських і океанських шляхів; здатність розв'язувати складні спеціалізовані задачі та практичні проблеми у сфері судноплавства та суднової інженерії, що передбачають застосування теорій і методів наук про устрій судна, навігацію, механічну та електричну інженерії, експлуатацію та ремонт засобів транспорту, управління ресурсами та характеризуються комплексністю та невизначеністю умов; уміння використовувати методи, методики та технології навігації, обробки та розміщення вантажів, управління операціями судна та піклування про людей на судні, морської інженерії, суднової електричної інженерії, автоматичного та автоматизованого управління, технічного обслуговування та ремонту, радіозв'язку (за спеціалізаціями); уміння використовувати інструменти, обладнання та системи, що забезпечують навігацію і управління морськими суднами, експлуатацію та ремонт морських транспортних засобів, безпеку судноплавства та охорону навколишнього середовища; володіння науковими та науково-дослідницькими методами для визначення умов і вимог під час розв'язання проблемних задач, знаходження шляхів їх вирішення та отримання належних результатів; здатність проводити дослідження.

Узагальнення і аналіз заповнених експертами анкет дозволило визначити показники професійно-особистісного критерію: здатність працювати в команді; доброзичливість, тактовність; чіткість і виразність мовлення, комунікабельність; емоційна стійкість, самовладання, витримка; організаторські здібності; фізична витривалість, швидкість реакції; дисциплінованість, законослухняність, зібраність, відповідальність; технічне і образне мислення, концентрація і переключення уваги.

Щодо методів, завдяки яким можна отримувати кількісні дані, то для показників потребнісно-мотиваційного критерію сформованості готовності майбутніх судноводіїв до професійної діяльності доцільно використовувати:

- методику Т. Дубовицької (інтерес до професії, рівень професійної спрямованості), “Методику визначення мотивації навчання” (В. Каташев), методику О. Зубрової (потреба у саморозвитку, самоосвіті та самовдосконаленні), методика “Діагностика рівня вимогливості до себе" (О. Зуброва), опитувальник професійної спрямованості (ОПС) Д. Голанда.

Для отримання кількісних даних за показниками ціннісно-орієнтаційного критерію сформованості готовності майбутніх судноводіїв до професійної діяльності доцільно використовувати:

- методику “Ціннісні орієнтацій” М. Рокіча в модифікації Д. Леонтьєва для вивчення рівнів структури системи ціннісних орієнтацій;

- тест сенс-життєвих орієнтацій (СЖО), розроблений Д. Леонтьєвим для визначення загального показника свідомості життя, зокрема мети життя, процесу життя, результативності життя, а також два аспекти локусу контролю;

- методику дослідження справжніх ціннісних орієнтацій особистості С. Бубнової для дослідження концепції ціннісних орієнтацій як системоутворюючого фактора особистості;

- опитувальник потреби в досягненнях Ю. Орлової, призначений для вивчення основних характеристик мотиваційно-потребнісної сфери; 


\section{ОСОБЛИВОСТІ ВИЗНАЧЕННЯ ПОКАЗНИКІВ СФОРМОВАНОСТІ ГОТОВНОСТІ МАЙБУТНІХ СУДНОВОДІЇВ ДО ПРОФЕСІЙНӦ̈ ДІЯЛЬНОСТІ}

\begin{abstract}
- методику визначення індексу групової згуртованості Сишора;

- метод спостереження за діями курсантів у різних ситуаціях навчальної діяльності та морської практики.

Для отримання кількісних даних за показниками когнітивного критерію сформованості готовності майбутніх судноводіїв до професійної діяльності доцільно використовувати результати оцінювання письмового та усного опитування, виконання тестів, письмового розв'язування ситуаційних завдань, контрольних і практичних робіт. Ці методи перевірки знань можуть бути використані під час звичайних форм організації освітнього процесу (під час лекцій, семінарських, практичних і лабораторних занять) і на спеціальних заняттях, організованих з метою оцінювання (колоквіуми, захист курсових і дипломних робіт, заліки та іспити).
\end{abstract}

Для отримання кількісних даних за показниками практичного критерію сформованості готовності майбутніх судноводіїв до професійної діяльності доцільно використовувати оцінювання: виконання практичних робіт, алгоритму та правильності дій курсантів під час їх участі у рольових і ділових іграх, оцінювання роботи в малих групах, оцінювання проектної роботи, оцінювання практичних занять, оцінювання дій у конкретних випадках (кейсах), оцінювання портфоліо робіт, тестування, письмове й усне опитування, виконання контрольних робіт, метод спостереження.

Висновки 3 даного дослідження i перспективи подальших розвідок у даному напрямку. Сформованість готовності майбутніх судноводіїв до професійної діяльності можна визначити за допомогою потребнісномотиваційного, иіннісно-орієнтаційного, когнітивного, професійно-особистісного та практичного критеріїв. Визначення і характеристика показників сформованості готовності майбутніх судноводіїв до професійної діяльності дозволяє з'ясувати стан сформованості готовності майбутніх судноводіїв до професійної діяльності в умовах традиційної системи навчання, а також оцінити ефективність авторських пропозицій щодо удосконалення цього процесу.

Перспективами подальших наукових розвідок у контексті розв'язання проблеми дослідження $\epsilon$ обгрунтування авторської концепції формування готовності майбутніх судноводіїв до професійно діяльності, а також розроблення інноваційної системи підготовки фахівців у сфері навігації і управління морськими суднами у морських закладах вищої освіти.

\section{ЛІТЕРАТУРА}

1. Барабанщиков А., Дерюгин Н. Военнопедагогическая диагностика. Москва, 1995. 108 с.

2. Білявець С.Я. Методична система формування професійної компетентності майбутніх офіцерів-прикордонників у процесі навчання військово-спеціальних дисциплін. Док. дис. 13.00.02, 13.00.04. Хмельницький, 2019 р., 565 с.

3. Білявець С. Я. Характеристика критеріїв i показників сформованостіпрофесійної компетентності майбутніх офіцерів-прикордонників. Innovative solutions in modern science. 2017. № 6 (15). C. 25-39.

4. Волошинов С. А. Алгоритмічна підготовка майбутніх судноводіїв з системою візуальної підтримки в умовах інформаційно-комунікаційного педагогічного середовища: автореф. дис. на здоб. наук. ступ. канд. пед. наук : 13.00.04 - теорія і методика професійної освіти. Херсонський держ. ун-т. Херсон, 2012. 20 с.

5. Герганов Л. Д. Теоретичні і методичні засади професійної підготовки кваліфікованих робітників морського транспорту на виробництві: дис. ... докт. пед. наук: 13.00.04. Київ, 2016. 485 с.

6. Демченко О. М. Професійна діяльність фахівців морського флоту як педагогічна проблема. Вісник Черкаського університету. Серія “Педагогічні науки”. Вип. № 6. 2016. C. 44-51.

7. Діденко О. В., Мішенюк Р. М. Критерії, показники і рівні розвиненості професійної компетентності офіцерів управління органами охорони державного кордону. Вісник Національного університету оборони України : зб. наук. пр., Київ, НУОУ, 2014. С. 74-80.

8. Дудікова Л. В. Критерії, показники та рівні сформованості професійно-етичної компетентності майбутніх лікарів. Virtus : scientific journal / Ed.-inChief M. A. Zhurba. 2018. № 20. Part 1. P. 119-123.

9. Дягилева О. Підготовка науково-педагогічних працівників ВНЗ морського профілю в контексті розвитку науково-дослідницького середовища. Наукові записки Кіровоградського державного педагогічного університету імені Володимира Винниченка. Сер. : Педагогічні науки. 2014, вип. 131. C. 94-98.

10. Погодаєва А. С. Аналіз професійної підготовки фахівців морського профілю $з$ точки зору компетентнісного підходу. Проблеми сучасної педагогічної освіти. Педагогіка і психологія. 2013, вип. 39(4). С. 124-128. 


\title{
ОСОБЛИВОСТІ ВИЗНАЧЕННЯ ПОКАЗНИКІВ СФОРМОВАНОСТІ ГОТОВНОСТІ МАЙБУТНІХ СУДНОВОДЇВ ДО ПРОФЕСІЙНОЇ ДІЯЛЬНОСТІ
}

11. Ткаченко К. Дослідження проблем системи підготовки фахівців водного та морського транспорту. Економічний аналіз. 2012, вип. 10, ч. 2. С. 71-75.

12. Чичикин, В. Профессиональная готовность и ее измерение. Человек в мире спорта : Новые идеи, технологии, перспективы : Тез. докл. Междунар. конгр. Москва, 1998. Т. 2. С. 491-492.

\section{REFERENCES}

1. Barabanschikov, A. \& Deryugin, N. (1995). Voenno-pedagogicheskaya diagnostika [Military pedagogical diagnostics]. Moscov, 108 p.[in Russian].

2. Biliavets, S. Ya. (2019). Metodychna systema formuvannia profesiinoi kompetentnosti maibutnikh ofitseriv-prykordonnykiv u protsesi navchannia viiskovo-spetsialnykh dystsyplin [Methodical system of formation of professional competence to future border guard officers in the process of training in military-special disciplines]. Extended abstract of Doctor's thesis. Khmelnytskyi, 565 p. [in Ukrainian].

3. Biliavets, S. Ya. (2017). Kharakterystyka kryteriiv i pokaznykiv sformovanosti profesiinoi kompetentnosti maibutnikh ofitseriv-prykordonnykiv [Characteristics of criteria and indicators for the formation of professional competence to future borderguards]. Innovative solutions in modern science. No.6 (15), pp. 25-39. [in Ukrainian].

4. Voloshynov, S. A. (2012). Alhorytmichna pidhotovka maibutnikh sudnovodiiv $\mathrm{z}$ systemoiu vizualnoi pidtrymky $\mathrm{v}$ umovakh informatsiinokomunikatsiinoho pedahohichnoho seredovyshcha [Algorithmic training of future navigators with a visual support system in the information and communication pedagogical environment]. Extended abstract of candidate's thesis. 20 p. [in Ukrainian].

5. Herhanov, L. D. (2016). Teoretychni i metodychni zasady profesiinoi pidhotovky kvalifikovanykh robitnykiv morskoho transportu na vyrobnytstvi [Theoretical and methodical bases for professional on-the-job training of qualified sea transport workers]. Extended abstract of Doctor's thesis. Kyiv, 485 p.[in Ukrainian].

6. Demchenko, O. M. (2016). Profesiina diialnist fakhivtsiv morskoho flotu yak pedahohichna problema [Professional activities of specialists of the navy as a pedagogical problem]. Cherkasy university bulletin: pedagogical sciences. Vol.6, pp. 44-51.[in Ukrainian].

7. Didenko, O. V. \& Misheniuk, R. M. (2014). Kryterii, pokaznyky i rivni rozvynenosti profesiinoi kompetentnosti ofitseriv upravlinnia orhanamy okhorony derzhavnoho kordonu [Criteria, indicators and levels of development of professional competence of the officers of the state border guard authorities.]. Bulletin of the National Defense University of Ukraine: Col. of Scient. Works. Kyiv, pp. 74-80.[in Ukrainian].

8. Dudikova, L. V. (2018). Kryterii, pokaznyky ta rivni sformovanosti profesiino-etychnoi kompetentnosti maibutnikh likariv [Criteria, indicators and levels of professional and ethical competence of future physicians]. Virtus : scientific journal. No. 20. Part 1,pp. 119-123.[in Ukrainian].

9. Diahyleva, O. (2014). Pidhotovka naukovopedahohichnykh pratsivnykiv VNZ morskoho profiliu v konteksti rozvytku naukovo-doslidnytskoho seredovyshcha [Training of scientific and pedagogical staff of maritime universities in the context of the development of the research environment]. Volodymyr Vynnychenko Central Ukrainian State Pedagogical University "Academic Commentaries. Series: Pedagogical Sciences". 2014, Vol. 131, pp. 94-98.[in Ukrainian].

10. Pohodaieva, A. S. (2013). Analiz profesiinoi pidhotovky fakhivtsiv morskoho profiliu $\mathrm{z}$ tochky zoru kompetentnisnoho pidkhodu [Analysis of professional training of marine specialists in terms of competencebased approach]. Problems of Modern Pedagogical Education. Series: pedagogy and psychology, Vol. 39(4), pp. 124-128. [in Ukrainian].

11. Tkachenko, K. (2012). Doslidzhennia problem systemy pidhotovky fakhivtsiv vodnoho ta morskoho transportu [Study of problems of the system of training of specialists of water and sea transport]. Economic analysis. Vol. 10, part 2, pp. 71-75. [in Ukrainian].

12. Chichikin, V. (1998). Professionalnaya gotovnost i ee izmerenie [Professional readiness and its measurement]. Man in the world of sports: New ideas, technologies, perspectives: Theses of rep. Intern. congr. Moscov. Vol. 2, pp. 491-492. [in Russian].

Стаття надійшла до редакції 12.06.2019

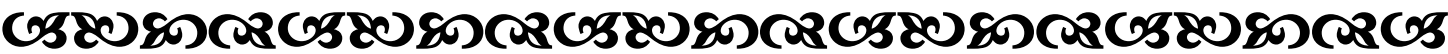

"Успіх приходить лише до тих, хто не залишає спроб домогтися свого і незмінно має позитивне світосприйняття".

\author{
Вільям Клемент Стоун \\ американсьқий бізнесмен, меценат
}

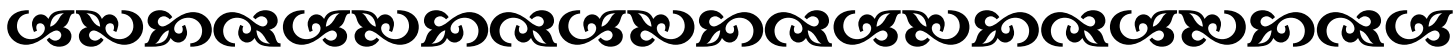

